\title{
DETERMINATION OF PHYSICAL AND ENGINEERING PROPERTIES OF TIGER NUT (Cyperus esculentus) RELEVANT TO ITS MECHANIZATION
}

\author{
Emurigho, Tega A \\ Department of Food Technology \\ Federal Polytechnic Nekede, Owerri, Nigeria
}

\author{
Kabuo, Canice O.O \\ Department of Food Science and Technology \\ Imo State University, Owerri, Nigeria
}

\author{
Ifegbo Arinze N \\ Department of Food Technology \\ Federal Polytechnic Nekede, Owerri, Nigeria
}

\begin{abstract}
The physical and engineering properties of fresh and dried tiger nut (Cyperus esculentus) were determined at moisture content of $41.20 \%$ and $16.40 \%$ on wet basis respectively. The mean values for the three principal axes (length, width and thickness) were $9.52 \mathrm{~mm}, 8.16 \mathrm{~mm}$, and $8.16 \mathrm{~mm}$ for fresh tiger nut and $9.14 \mathrm{~mm}, 7.72 \mathrm{~mm}$ and $8.03 \mathrm{~mm}$ for dried tiger nut respectively, showing a decrease with decrease in moisture content and was significantly different at $\mathbf{p}<0.05$. The mean values of the bulk density, true density and porosity of both fresh and dried tiger nut were $0.59 \mathrm{~g} / \mathrm{cm}^{3}, 0.97 \mathrm{~g} / \mathrm{cm}^{3}, 40.61$ and $0.58 \mathrm{~g} / \mathrm{cm}^{3}$, $0.94 \mathrm{~g} / \mathrm{cm}^{3}, 40.35$ respectively and were not significantly different at $p<0.05$. The mean angle of repose and coefficient of static friction over formica, stainless steel, glass and plywood surfaces of fresh tiger nut were $50.11^{\circ}, 2.73,2.45,2.22$ and 1.77 while that of dried tiger nut were $48.23^{\circ}, 2.41$, $2.03,2.11$ and 2.00 respectively. The mean rupture force increased with compression force of $90.08 \mathrm{~N}$ on the major axis to $116.88 \mathrm{~N}$ for fresh tiger nut and from $120.55 \mathrm{~N}$ to $161.10 \mathrm{~N}$ for dried tiger nut and were significantly different at $p<0.05$. These properties determined are necessary in the design and fabrication of hoppers, conveyor equipment and the force tiger nut can withstand before it is ruptured.
\end{abstract}

Keywords: Tiger nut, physical, engineering, equipment design and fabrication

\section{INTRODUCTION}

Tiger nut (Cyperus esculentus), is an emergent grasslike plant belonging to the sedge family. Tiger nut is a fast-growing plant taking an average of three months till maturity and is often mistaken for weeds in some areas. The weedy or wild type, although closely related to tiger nut is different and known as yellow nut sedge as reported by Gerald and Bonny (1976); (Dyer (2006). Tiger nut is preferably grown in well-drained sandy or loamy soils and its production increases as the ambient temperature increases according to Bamishaiye and Bamishaiye (2011). Anon (1992) emphasized it is widely distributed in the temperate zones within South Europe as its probable origin and has become naturalized in Ghana, Nigeria and Sierra-Leone. In Nigeria, tiger nut is usually available in the markets where it is sold locally and consumed even uncooked as fresh, semi-dried and dried form. Tiger nut contains about $8 \%$ protein and has $20-30 \%$ tiger nut oil, which is nourishing to the epidermis as reported by Alobo and Ogbodo (2007). Oladele and Aina (2007) acknowledged that the necessary essential minerals, calcium, magnesium and iron required for bones, tissue repairs, muscles and bloodstream, as well as vitamin B that assist in balancing the central nervous system are contained in tiger nut tubers. Chevalier (1996) also reported that tiger nut tuber could be used for the treatment of flatulence, indigestion, diarrhoea, dysentery and excessive thirst and contains higher essential amino acids than those proposed in the protein standard by the FAO/WHO (1985) for satisfying adult needs according to Bosch and Farre (2005). 
The physical and engineering properties which are relevant to the mechanization of harvesting, handling, and processing of seeds to increase their utilization as food industrial raw material sources, should be determined. Agricultural produce especially those of plant origin have unique physical and engineering properties different from seed to seed, nut to nut, fruit to fruit and grain to grain. These produce are now frequently used for a wide range of activities while their economic importance has increased with the complexity of new technology for storage, production, handling and preservation. Hence, understanding the physical and engineering properties of these agricultural produce such as tiger nut is important for its use in process design and aids in the mechanization of its processing in the design of machines to be used during harvesting, cleaning, handling and storage etc.

In most countries, processing of tiger nut into a different product such as flour and beverage is challenging to the producers and as a result of this, there is need to ensure all potentials of tiger nut are exploited effectively and utilized industrially. For it to be utilized industrially, engineers will need information on its physical and engineering properties. However, it is essential to understand the physical laws guiding the response of this agricultural produce so that machines, process and handling operation can be designed for maximum efficiency and the highest quality of the final product. Hence, there is a need for information on the physical and engineering properties which is important in the design of agricultural machinery and equipment.

Researchers have done several works on the physical and engineering properties of nuts, grains, seeds, fruits and vegetables as reported by Pius and Phumuza, (2014); Opadotun et al. (2016); Felix and Anthony (2011); Karpoora et al. (2013); Orhevba et al. (2013); Gursoy and Guzel (2010), as well as processing and preservation Belewu and Belewu (2007); Ade-Omowaye et al.. (2008), and on the effect of moisture content on the physical properties of black variety tiger nut Abano and Amoah (2011), no work has been done on the physical and engineering properties of yellow variety tiger nut to ascertain suitable machinery for its process and utilization.

\section{MATERIALS AND METHODS}

\section{A. Source of materials}

The fresh and dried tiger nut used for the determination of the physical and engineering properties was procured from Ama Hausa market in
Owerri, Imo State, Nigeria. Tiger nut was thoroughly sorted and cleaned to remove foreign materials, dirt and contaminated ones. The thoroughly cleaned and sorted tiger nut was coded as fresh tiger nut (sample A) and dried tiger nut (sample B). These coded samples were then used in the determination of the physical and engineering properties.

\section{B. Determination of moisture content}

Moisture content was determined according to AOAC (1990). The weight of each dried empty dish was recorded and 5 grams of tiger nut both fresh and dried was evenly spread on each dish respectively. The weight of the sample and dish was taken for both fresh and dried tiger nut. The weighed samples were then dried in an oven for 3 hours at $105^{\circ} \mathrm{C}$ and cooled in a glass desiccator for 30 minutes after which the weight of samples and dish were again recorded. It was later transferred into the oven for another 30 minutes, cooled and re-weighed and the process repeated until a constant weight was recorded. The moisture content was then calculated using the formula on percentage wet basis (\% w.b) as shown in equation 1

$$
\mathrm{Mc}=\frac{\mathrm{W} 2-\mathrm{W} 1}{W 3-W 1} \times 100
$$

Where Mc is moisture content on wet basis (\%), $\mathrm{W}_{1}$ is weight of the empty dish $(\mathrm{g}), \mathrm{W}_{2}$ is weight of dish and sample before drying $(\mathrm{g}), \mathrm{W}_{3}$ is weight of dish and sample after drying $(\mathrm{g})$.

\section{B. PHYSICAL PROPERTIES}

\section{Determination of weight}

The weights of 30 tiger nut were determined by using an electronic weighing balance. Each of the 30 tubers of tiger nut was weighed and the readings were recorded and the mean value was taken according to Sirisomboon et al. (2007).

\section{Determination of size}

Thirty (30) tiger nuts of both samples (fresh and dried) were selected randomly. The size was determined using the axial dimension; length, width and thickness which represent the major, intermediate and minor diameters. These principal dimensions were measured using a digital Vernier Calliper (TA, M5, 0-300mm model, China) with $0.01 \mathrm{~mm}$ precision. The readings were recorded and the mean value was taken. 


\section{Determination of geometric mean diameter (Dg)}

The geometric mean diameter was determined from the major (L), intermediate (W) and minor (T) diameter using the formula by Heidarbeigi et al. (2013) in equation 2. The readings were recorded and the mean value was taken.

$(\mathrm{Dg})=\sqrt[3]{L W T}(\mathrm{~mm})$

Where; $\mathrm{L}=$ (major) length, $\mathrm{W}=$ (intermediate) width, $\mathrm{T}=$ (minor) thickness

\section{Determination of arithmetic mean diameter} (Da)

The arithmetic mean diameter was determined from the three principle diameter using the relationship by Mohsenin (1986) in equation 3. The mean readings were recorded.

$\mathrm{Da}=\frac{a+b+c}{3} \quad(\mathrm{~mm})$

where $\mathrm{Da}=$ arithmetic mean, $\mathrm{a}=$ length, $\mathrm{b}=$ width, $\mathrm{c}$ $=$ thickness.

V. Determination of surface area (Sa) and volume $(\mathbf{V})$

The surface area was determined by using the following equation as cited by Tunde-Akintunde and Akintunde (2014) and Altunas and Demirtola (2007) in equations 4 . The mean readings were recorded.

$\mathrm{Sa}=\pi \mathrm{Dg}^{2}$

Where $\mathrm{Dg}$ is geometric mean diameter, $\mathrm{Sa}=$ Surface area, $\pi=3.142$

Volume (V) in $\mathrm{mm}^{3}$ was calculated using the equation below by Ebrahimzadeh et al. (2013).

$\mathrm{V}=\frac{\pi D g 3}{6}$

Where Dg $=$ Geometric mean diameter $(\mathrm{mm}), \pi=$ 3.142

\section{Determination of shape}

From the axial dimensions, tiger nut shape was described numerically by calculating Sphericity index (ф) as percentage and Aspect ratio (Ra) using equations described by Gursoy and Guzel, (2010) in equations 6and 7. The mean readings will be recorded.

Sphericity $\Phi=\left(\frac{D g}{\mathrm{a}}\right) \times 100$

where $\mathrm{Dg}=$ Geometric mean diameter $\mathrm{a}=$ length

Aspect ratio $(\mathrm{Ra})=\frac{W}{L}$,

Where $\mathrm{W}=$ width, $\mathrm{L}=$ length

Flakiness ratio $(\mathrm{Rf})=\frac{T}{W}$

Ebrahimzadeh et al. (2013). Where $\mathrm{T}=$ thickness; $\mathrm{W}=$ width

\section{GRAVIMETRIC PROPERTIES}

\section{Determination of true density}

True density was obtained by dividing the mass of the sample by its volume determined by solvent (water) displacement as described by Dutta et al. (1998). Fifty gram $(50 \mathrm{~g})$ of tiger nut was poured into a measuring cylinder containing $50 \mathrm{~cm}^{3}$ of distilled water. The volume of water displaced and weight of the sample was recorded, which was used to calculate the true density, and expressed in $\mathrm{g} / \mathrm{cm}^{3}$.

True density $=\frac{\text { Weight of sample }}{\text { Volume of } \text { water displaced }}$

\section{Determination of bulk density}

The average bulk density of the tiger nut was determined by weighing the nuts packed in $250 \mathrm{~cm}^{3}$ measuring cylinder Heidarbeigi et al. (2013). The packed nuts in the measuring cylinder were gently tapped to allow them to settle. The volume of the measuring cylinder occupied by the tiger nut was recorded and the weight taken using an electronic weighing balance. The bulk density was calculated in $\mathrm{g} / \mathrm{cm}^{3}$ using the formula;

Bulk density $(\mathrm{Pb})=\frac{\text { Weight of material packed }}{\text { bulk volume }}$

\section{Determination of porosity}

Porosity (E) was computed as a percentage of the true and bulk densities using the equation below as described by Varnamkhasti et al .(2007)

$\mathrm{E}=1-\frac{P b}{P t} \times 100$ 
Where $P b=$ Bulk density, $P t=$ True density

\section{ENGINEERING PROPERTIES}

\section{Determination of angle of repose}

The angle of repose was determined by piling the tiger nut over a horizontal surface of known height. The diameter of the pile was recorded from the circumference of the pile and the height of the pile determined. The angle of repose was calculated using the formula according to Ebrahimzadeh et al. (2013).

$$
\begin{aligned}
& \text { Angle of repose } \Theta=\tan ^{-1}(2 H / D) \\
& (12)
\end{aligned}
$$

Where $\Theta=$ Angle of repose

$\mathrm{H}=$ Height of the pile

$\mathrm{D}=$ Diameter of the pile

\section{Determination of coefficient of static friction}

The static coefficient of friction $(\mu)$ was determined for each of the following structurally materials namely formica, plywood, stainless steel, and glass according to the method by Orhevba et al. (2013). A four-sided Formica with dimensions of $150 \mathrm{~m} \mathrm{x}$ $100 \mathrm{~mm} \times 40 \mathrm{~mm}$ opened at both the top and bottom was filled with tiger nuts after placing it on an adjustable tilting surface. The structural surface with the box on its top was gradually raised until the box just started to slide down. The angle of inclination was read from a graduated scale and the coefficient of friction taken as the tangent of the angle. The procedure was repeated for the other structural materials.

$\mu=\tan \beta$

where $\mu=$ coefficient of static friction for the structural material, $\beta=$ angle of inclination

NOTE: $\beta=\tan ^{-1}$ i.e. $\frac{\text { Vertical height of inclined plane }}{\text { base length of the platform }}$

\section{Determination of compression force}

The compression force on the tiger nut was determined using a force gauge with model no: FG 105-500N from Amittari Instruments, Hong Kong. The test was carried out on the major and minor axes of the tiger nut. The tiger nut was placed between a screwed jaw with a $500 \mathrm{~N}$ load cell and was compressed. Compression readings were taken immediately the tiger nut was ruptured. The rupture point is the point at which the grain gets break or crack according to Fos'hat et al. (2011); Mohapatra and Bal (2012). The procedure was repeated 4 times for each axis.

\subsection{STATISTICAL ANALYSIS}

The results obtained were subjected to statistical analysis. Statistical Package for Social Sciences (SPSS) version 23 was used to analyse for the minimum, maximum, mean and standard deviation. T-test was used to separate the means at 5\% level of significant difference.

\section{RESULTS AND DISCUSSION}

\section{A. PHYSICAL PROPERTIES}

The results of the physical properties of fresh and dried tiger nut with the moisture content of $41.20 \%$ and $16.40 \%$ wet basis as shown in Table 1 and 2 .

The mean values of the three principal dimensions (length, width and thickness) of the fresh tiger nut $9.52 \mathrm{~mm}, 8.16 \mathrm{~mm}$ and $8.91 \mathrm{~mm}$ decreased to $9.14 \mathrm{~mm}$, $7.72 \mathrm{~mm}$ and $8.03 \mathrm{~mm}$ respectively for the dried tiger nut as a result of the decrease in moisture content (from 41.20 to $16.40 \%$ ). These values have a similar trend as reported by Abano and Amoah, (2011) and Ahmet et al. (2017). This decrease in value is attributed to the removal of water from the cellular structure of the tiger nut. This removal or transport of water from the cellular locations to the surrounding environment-induced significant variations or difference at $\mathrm{p}<0.05$ of the three principal dimensions of the tiger nut. The same decrease in values with a decrease in moisture content was observed for the weight $(0.90 \mathrm{~g}$ to $0.64 \mathrm{~g})$, arithmetic mean diameter $(8.86 \mathrm{~mm}$ to $8.28 \mathrm{~mm})$ and geometric mean diameter $(8.82 \mathrm{~mm}$ to $8.26 \mathrm{~mm})$ which were significantly different at $\mathrm{p} \leq 0.05$. Though these values are lower than that of dika nut reported by Orhevba et al. (2013) and morana bean by Pius and Phumuza (2014) but close to that reported by Ahmet et al. (2017). These mentioned dimensions (length, width, thickness, arithmetic and geometric mean diameters) are much important in the design of machines used in the separation of agricultural product from undesirable materials and the development of sizing, grading, cleaning, sieving equipment, and storage facilities. 
International Journal of Engineering Applied Sciences and Technology, 2020

Vol. 5, Issue 8, ISSN No. 2455-2143, Pages 82-90

Published Online December 2020 in IJEAST (http://www.ijeast.com)

Table 1.

\begin{tabular}{|c|c|c|c|c|}
\hline $\begin{array}{l}\text { Properties } \\
\text { S.D }\end{array}$ & $\mathrm{N}$ & Maxi & Mini & Mean \\
\hline $\begin{array}{l}\text { Weight (g) } \\
0.42\end{array}$ & 30 & 1.94 & 0.53 & $0.90 \mathrm{a}$ \\
\hline $\begin{array}{l}\text { Length }(\mathrm{mm}) \\
0.26\end{array}$ & 30 & 9.98 & 9.05 & $9.52 \mathrm{a}$ \\
\hline $\begin{array}{l}\text { Width (mm) } \\
1.12\end{array}$ & 30 & 9.68 & 5.47 & $8.16 \mathrm{a}$ \\
\hline $\begin{array}{l}\text { Thickness (mm) } \\
0.82\end{array}$ & 30 & 9.92 & 7.04 & $8.91 \mathrm{a}$ \\
\hline $\begin{array}{l}\text { Arithmetic mean } \\
\text { diameter }(\mathrm{mm}) \\
0.56\end{array}$ & 30 & 9.73 & 7.72 & $8.86 a$ \\
\hline $\begin{array}{l}\text { Geometric mean } \\
\text { diameter }(\mathrm{mm}) \\
0.60\end{array}$ & 30 & 9.73 & 7.64 & $8.82 \mathrm{a}$ \\
\hline $\begin{array}{l}\text { Surface area }\left(\mathrm{mm}^{2}\right) \\
32.82\end{array}$ & 30 & 297.46 & 183.40 & $245.62 \mathrm{a}$ \\
\hline $\begin{array}{l}\text { Volume }\left(\mathrm{mm}^{3}\right) \\
71.99\end{array}$ & 30 & 482.32 & 233.53 & $384.35 \mathrm{a}$ \\
\hline $\begin{array}{l}\text { Sphericity }(\%) \\
7.64\end{array}$ & 30 & 100.00 & 82.00 & $97.07 \mathrm{a}$ \\
\hline $\begin{array}{l}\text { Aspect ratio }(\mathrm{Ra}) \\
0.12\end{array}$ & 30 & 1.00 & 0.57 & $0.86 \mathrm{a}$ \\
\hline $\begin{array}{l}\text { Flakiness ratio (RF) } \\
0.18\end{array}$ & 30 & 1.76 & 0.87 & $1.09 \mathrm{a}$ \\
\hline
\end{tabular}

Mean with different alphabet on row are significantly different at $p<0.05$

$\mathrm{N}=$ number of observation, Maxi=maximum, Mini=minimum, $\mathrm{SD}=$ standard deviation

The surface area of an agricultural product is generally indicative of its pattern of behaviour in a flowing fluid such as air, as well as the ease of using pneumatic means to separate extraneous materials from the product during cleaning emphasized by Omobuwajo (1999). It is also important in heat and mass transfer processes such as drying and other thermal applications. From the mean surface area values obtained for fresh tiger nut $\left(245.62 \mathrm{~mm}^{2}\right)$ and dried tiger nut $\left(215.21 \mathrm{~mm}^{2}\right)$, this indicates that the fresh tiger nut will be easier to separate extraneous materials from it as well as transfer heat faster during thermal operations than the dried tiger nut but will have better storage because of its small surface area by absorbing less moisture.

Table 2. Mean values of dried tiger nut

\begin{tabular}{lcccc}
\hline $\begin{array}{l}\text { Properties } \\
\text { S.D }\end{array}$ & $\mathrm{N}$ & Maxi & Mini & Mean \\
\hline $\begin{array}{l}\text { Weight (g) } \\
0.42\end{array}$ & 30 & 1.94 & 0.53 & $0.90 \mathrm{a}$ \\
$\begin{array}{l}\text { Length (mm) } \\
0.26\end{array}$ & 30 & 9.98 & 9.05 & $9.52 \mathrm{a}$ \\
& & & &
\end{tabular}

\begin{tabular}{|c|c|c|c|c|}
\hline $\begin{array}{l}\text { Width (mm) } \\
1.12\end{array}$ & 30 & 9.68 & 5.47 & 8.16 \\
\hline $\begin{array}{l}\text { Thickness }(\mathrm{mm}) \\
0.82\end{array}$ & 30 & 9.92 & 7.04 & 8.9 \\
\hline $\begin{array}{l}\text { Arithmetic mean } \\
\text { diameter }(\mathrm{mm}) \\
0.56\end{array}$ & 30 & 9.73 & 7.72 & \\
\hline $\begin{array}{l}\text { Geometric mean } \\
\text { diameter }(\mathrm{mm}) \\
0.60\end{array}$ & 30 & 9.73 & 7.64 & 8.8 \\
\hline $\begin{array}{l}\text { Surface area }\left(\mathrm{mm}^{2}\right) \\
32.82\end{array}$ & 30 & 297.46 & 183.40 & 245.6 \\
\hline $\begin{array}{l}\text { Volume }\left(\mathrm{mm}^{3}\right) \\
71.99\end{array}$ & 30 & 482.32 & 233.53 & 384.3 \\
\hline $\begin{array}{l}\text { Sphericity }(\%) \\
7.64\end{array}$ & 30 & 100.00 & 82.00 & 97.0 \\
\hline $\begin{array}{l}\text { Aspect ratio }(\mathrm{Ra}) \\
0.12\end{array}$ & 30 & 1.00 & 0.57 & 0.8 \\
\hline lakiness ratio (RF) & & 1.76 & 0.87 & \\
\hline
\end{tabular}

0.18

Mean with different alphabet on row are significantly different at $p<0.05$

$\mathrm{N}=$ number of observation, Maxi=maximum, Mini=minimum, $\mathrm{SD}=$ standard deviation

The mean volume of the tiger nut also decreased with a decrease in moisture content significantly at $\mathrm{p}<0.05$ from $364.35 \mathrm{~cm}^{3}$ to $298.96 \mathrm{~cm}^{3}$. This volume change or shrinkage is caused by reduction of water from the tiger nut during drying as a result of its inability to hold its structural arrangement when the space occupied by water is constantly emptied and air-filled and the collapse of its exterior skin structure reported by Khan et al. (2016b); Panyawong and Devahastin (2007). From the values obtained, it will be more economical in the design of storage facility for the dried tiger nut compared to the fresh tiger nut because of the volume $\left(17.95 \mathrm{~cm}^{3}\right)$ it during drying.

Sphericity, aspect and flakiness ratios are some indices used to measure and characterise the shape of agricultural materials according to Ebrahimzadeh et al. (2013); Sitkei (1986). The mean sphericity, flakiness and aspect ratios of the fresh and dried tiger nut are $97.07 \%, 0.86,1.09$ and $90.46 \%, 0.85$ and 1.06 respectively. These values are similar to the values reported by Abano and Amoah, (2011) and followed the same trend of decrease with decreased moisture content but higher than dika nut, morana bean, cowpea reported by Orhevba et al. (2013; Pius and Phumuza (2014); Chukwu and Summonu (2010), flakiness and aspect ratio were found to be $96 \%, 1.2$ and 0.86 respectively. The high mean sphericity of both fresh and dried tiger nut though significantly different at $\mathrm{p} \leq 0.05$ indicates that the tuber is likely to 
roll than slide on flat surface but the mean flakiness and aspect ratios are not significantly different at $p<0.05$. These values of sphericity, flakiness and aspect ratios are important in the design of machine hopper to handle the tiger nut.

\section{B. GRAVIMETRIC PROPERTIES}

The mean bulk density, true density and porosity were found to be $0.59 \mathrm{~g} / \mathrm{cm}^{3}, 0.97 \mathrm{~g} / \mathrm{cm}^{3}$ and $40.61 \%$ for fresh tiger nut and $0.58 \mathrm{~g} / \mathrm{cm}^{3}, 0.98 \mathrm{~g} / \mathrm{cm}^{3}$ and $40.35 \%$ for dried tiger nut respectively as shown in Tables 3 and 4 .

These values showed no significant difference at $\mathrm{p}<0.05$ but are higher than seeds and kernels of Jatropha curcas L, African star apple seeds reported by Shkelqim and Joachim (2010); Opadotun et al. (2016) and similar to Tamarind fruit by Karpoora et al. (2013). The fact that the determined densities of the tiger nut are less than the density of water that is $1.00 \mathrm{~g} / \mathrm{cm}^{3}$, floatation equipment can be used to separate good tiger nut from bad ones. More so, it is useful in the design and fabrication of hoppers and storage facilities. Heidarbeigi et al. (2013) reported that grain densities have been of interest in breakage susceptibility and hardness studies.

Table 3. Mean values of fresh tiger nut

\begin{tabular}{|c|c|c|c|c|}
\hline $\begin{array}{l}\text { Properties } \\
\text { S.D }\end{array}$ & $\overline{1}$ & Maxi & Mini & Mean \\
\hline $\begin{array}{l}\text { Bulk density }\left(\mathrm{g} / \mathrm{cm}^{3}\right) \\
0.03\end{array}$ & 4 & 0.61 & 0.54 & $0.59 a$ \\
\hline $\begin{array}{l}\text { True density }\left(\mathrm{g} / \mathrm{cm}^{3}\right) \\
0.03\end{array}$ & 4 & 1.00 & 0.94 & $0.97 \mathrm{a}$ \\
\hline $\begin{array}{l}\text { Porosity } \\
3.99\end{array}$ & 4 & 46.00 & 36.60 & $40.61 \mathrm{a}$ \\
\hline
\end{tabular}

$\mathrm{N}=$ number of observation, Maxi=maximum, Mini=minimum, $\mathrm{SD}=$ standard deviation

Table 4. Mean values of dried tiger nut

\begin{tabular}{|c|c|c|c|c|}
\hline $\begin{array}{l}\text { Properties } \\
\text { S.D }\end{array}$ & $\mathrm{N}$ & Maxi & Mini & Mean \\
\hline $\begin{array}{l}\text { Bulk density }\left(\mathrm{g} / \mathrm{cm}^{3}\right) \\
0.02\end{array}$ & 4 & 0.60 & 0.56 & $0.58 a$ \\
\hline $\begin{array}{l}\text { True density }\left(\mathrm{g} / \mathrm{cm}^{3}\right) \\
0.03\end{array}$ & 4 & 1.00 & 0.94 & $0.98 \mathrm{a}$ \\
\hline $\begin{array}{l}\text { Porosity } \\
3.04\end{array}$ & 4 & 44.00 & 36.60 & $40.35 a$ \\
\hline \multicolumn{5}{|c|}{$\begin{array}{l}\text { Mean with different alphabet on row are significantly } \\
\text { different at } p<0.05\end{array}$} \\
\hline $\begin{array}{l}\mathrm{N}=\text { number } \quad \text { of } \\
\mathrm{Mini}=\text { minimum, } \mathrm{SD}=\end{array}$ & & oservation, & & $=$ maximum \\
\hline
\end{tabular}

The low values of the mean porosity obtained indicates that to aerate and dry tiger nut, the fan and motor that will be used for the design of equipment for aeration and drying should be of high power because of its resistance to air and heat flow to reduce residence time during this process. In other words, porosity affects the rate of heat and mass transfer of moisture during aeration and drying processes.

\section{ENGINEERING PROPERTIES}

The mean angle of repose and coefficient of static friction on Formica, stainless steel, glass and plywood surfaces of fresh and dried tiger nut are presented in Tables 5 and 6.

The values of the angle of repose showed no significant difference at $\mathrm{p} \leq 0.05$ though is higher than varieties of tiger nut reported by Ahmet et al. (2017). This result showed that tiger nut will flow slowly, hence during the design and fabrication of hoppers and emptying bins, the angle of inclination, in other words, its slope should be a bit higher if fast flow or movement of tiger nut is desired.

The highest mean value of the static coefficient of friction of the fresh and dried tiger nut was recorded on the Formica surface, which is higher than the other three surfaces. The coefficient of static friction of the fresh and dried tiger nut is significantly different $(\mathrm{p}<0.05)$ on two surfaces, Formica $(2.73$ and 2.55) and stainless steel (2.45 and 2.03) but not significantly different $(\mathrm{p}<0.05)$ on the other two surfaces, glass (2.22 and 2.11) and plywood (1.77 and 2.00). This information is necessary for the design of conveying equipment for tiger nut within the processing plant.

Table 5 Mean values of fresh tiger nut

\begin{tabular}{|c|c|c|c|c|}
\hline $\begin{array}{l}\text { Properties } \\
\text { S.D }\end{array}$ & $\overline{\mathrm{N}}$ & Maxi & Mini & Mean \\
\hline $\begin{array}{l}\text { Angle of repose }\left({ }^{0}\right) \\
2.66\end{array}$ & 4 & 53.25 & 47.80 & $50.11 \mathrm{a}$ \\
\hline Static coefficient of & fricti & & & \\
\hline $\begin{array}{l}\text { Formica } \\
0.14\end{array}$ & 4 & 2.90 & 2.57 & $2.73 \mathrm{a}$ \\
\hline $\begin{array}{l}\text { Stainless steel } \\
0.13\end{array}$ & 4 & 2.64 & 2.23 & $2.45 a$ \\
\hline $\begin{array}{l}\text { Glass } \\
0.15\end{array}$ & 4 & 2.42 & 2.07 & $2.22 \mathrm{a}$ \\
\hline $\begin{array}{l}\text { Plywood } \\
0.43\end{array}$ & 4 & 1.81 & 1.71 & $1.77 \mathrm{a}$ \\
\hline CF (N) length axis & 4 & 94.80 & 84.60 & $90.08 \mathrm{a}$ \\
\hline
\end{tabular}


CF (N) width axis $\quad 4 \quad 123.20 \quad 107.40 \quad 116.88 \mathrm{a}$

6.78

Mean with different alphabet on row are significantly different at $p<0.05$

$\mathrm{N}=$ number of observation, Maxi=maximum, Mini=minimum, $\quad \mathrm{SD}=$ standard deviation, $\mathrm{CF}$ $(\mathrm{N})=$ compression force (Newton)

Table 6. Mean values of fresh tiger nut

\begin{tabular}{|c|c|c|c|c|}
\hline $\begin{array}{l}\text { Properties } \\
\text { S.D }\end{array}$ & \multicolumn{2}{|c|}{ N $\quad$ Maxi } & Mini & Mean \\
\hline $\begin{array}{l}\text { Angle of repose }\left(^{0}\right) \\
5.15\end{array}$ & 4 & 53.10 & 42.70 & $48.23 a$ \\
\hline \multicolumn{5}{|c|}{ Static coefficient of friction; } \\
\hline $\begin{array}{l}\text { Formica } \\
0.12\end{array}$ & 4 & 2.55 & 2.25 & $2.41 \mathrm{~b}$ \\
\hline $\begin{array}{l}\text { Stainless steel } \\
0.06\end{array}$ & 4 & 2.10 & 1.97 & $2.03 \mathrm{~b}$ \\
\hline $\begin{array}{l}\text { Glass } \\
0.06\end{array}$ & 4 & 2.19 & 2.06 & $2.11 \mathrm{a}$ \\
\hline $\begin{array}{l}\text { Plywood } \\
0.19\end{array}$ & 4 & 2.16 & 1.73 & $2.00 \mathrm{a}$ \\
\hline $\begin{array}{l}\text { CF (N) length axis } \\
9.61\end{array}$ & 4 & 132.10 & 110.40 & $120.55 b$ \\
\hline $\begin{array}{l}\text { CF }(\mathrm{N}) \text { width axis } \\
7.99\end{array}$ & 4 & 169.70 & 153.30 & $161.10 b$ \\
\hline \multicolumn{5}{|c|}{$\begin{array}{l}\text { Mean with different alphabet on row are significantly } \\
\text { different at } p<0.05\end{array}$} \\
\hline $\begin{array}{l}\mathrm{N}=\text { number } \\
\text { Mini=minimum, } \\
(\mathrm{N})=\text { compression for }\end{array}$ & $\begin{array}{r}\mathrm{ob} \\
\mathrm{SD}= \\
\mathrm{ce}(\mathrm{N}\end{array}$ & $\begin{array}{l}\text { servation } \\
\text { standard } \\
\text { ewton) }\end{array}$ & $\begin{array}{r}\text { Ma } \\
\text { devi }\end{array}$ & $\begin{array}{l}\mathrm{i}=\text { maximum, } \\
\text { ation, } \quad \mathrm{CF}\end{array}$ \\
\hline
\end{tabular}

The mean results of the compression force on the longitudinal (major or length) and horizontal (minor or width) axes of the fresh and dried tiger nut is shown in Tables 5 and 6 respectively. The force required to rupture the tiger nut on both axes increased with decrease in moisture content and were significantly different at $\mathrm{p}<0.05$. This could be as a result of the thickness of skin caused by shrinkage associated with loss of moisture from the internal cell structure that significantly $(\mathrm{p}<0.05)$ affected the three principal (length, width and thickness) axes. These results follow a similar trend of Pistachio Kernel, Macadamia nut, Hazel nut and Shea nut reported by Razavi and Edalatian (2012); Ayin (2002); Braga et al. (1999); Olaniyan and Oje, 2002). Compression position increased the force required to rupture fresh tiger nut from $90.08 \mathrm{~N}$ to $120.55 \mathrm{~N}$ on the length (longitudinal axis) while that of dried tiger nut increased from $120.55 \mathrm{~N}$ to $1161.10 \mathrm{~N}$ on the width (horizontal axis) because of the surface area of contact between the tiger nut and the compression plates of the force gauge from small to large surface area respectively. This result is useful in the design and fabrication of post-harvest machines such as harvester, extractor for tiger nut milk and oil as well as milling machine for tiger nut flour.

\section{CONCLUSION}

The physical properties such as the length, width, thickness, arithmetic mean diameter, geometric mean diameter, surface area, volume and sphericity of fresh and dried tiger nut were significantly different at $\mathrm{p}<0.05$ as a result of the reduction in moisture content. However, there was no significant difference at $\mathrm{p}<0.05$ for aspect and flakiness ratios even with decreased moisture content. Likewise, the bulk density, true density and porosity also showed no significant difference at $\mathrm{p}<0.05$ with a decrease in moisture content. Similarly, the angle of repose and coefficient of static friction on glass and plywood surfaces were not significantly different at $p<0.05$ but were significantly different at $\mathrm{p}<0.05$ for Formica and stainless steel surfaces. The highest mean result of 2.73 was recorded for Formica while the lowest mean result was recorded for plywood. Conversely, compression force increased from $90.08 \mathrm{~N}$ to $120.55 \mathrm{~N}$ and $116.88 \mathrm{~N}$ to $161.10 \mathrm{~N}$ with decreased moisture content but increased on loading or compression position from $90.08 \mathrm{~N}$ to $116.88 \mathrm{~N}$ and $120.55 \mathrm{~N}$ to $161.10 \mathrm{~N}$ for fresh and dried tiger nut respectively.

Conclusively, the amount of moisture on the tiger nut significantly at $\mathrm{p}<0.05$ affected the physical and engineering properties of fresh and dried tiger nut. Hence, it is very important and necessary in determining the physical and engineering properties of tiger nut that are relevant to design and fabrication of machine and equipment needed for its effective utilisation and mechanization processes.

\section{ACKNOWLEDGEMENT}

We sincerely acknowledge and thank laboratory staff of Food Quality Control, Department of Food Technology, Federal Polytechnic, Nekede, Owerri for their technical support.

\section{REFERENCES}

[1] Abano, E.E. and Amoah, K.K.,(2011). Effect of Moisture Content on the physical properties of Tiger nut (Cyperus esculentus). Asian Journal of Agricultural Research; 1(10), 1819-1894

[2] Ade-Omowaye, B.I.O., Akinwande, B.A., Bolarinwa, I.F. and Adebiyi, A.O. (2008). Evaluation of tiger nut (Cyperus esculentus)- 


\section{International Journal of Engineering Applied Sciences and Technology, 2020 Vol. 5, Issue 8, ISSN No. 2455-2143, Pages 82-90 \\ Published Online December 2020 in IJEAST (http://www.ijeast.com)}

wheat composite flour and bread. African Journal of Food Science; (2), 087-091.

[3] Ahmet, I., Kubilay, K. V., Yasemin, V., Pınar, Ç. and Melih, Y. Ç. (2017). Selected engineering properties of tiger nut as a function of moisture content and variety. Turk $J$ Agric For; DOI:10.3906/tar-1612-38

[4]Alobo, A. P. and Ogbodo, P.O. (2007) Selected properties of Tiger nut starch as affected by physical and chemical modifications. Proceeding of the $31^{\text {st }}$ annual NIFST Conference, Abuja, Nigeria $22^{\text {nd }}-25^{\text {th }}$ October 2007. pp 31-34

[5] Altunas, E. and Demirtola, H. (2007). Effect of moisture content on physical properties of some grain legume seed. New Zealand Journal of crop and horticulture science; 35(4), 423 - 433.

[6] A.O.A.C.(1990). Official Methods of Analysis. $15^{\text {th }}$ edition. Arlington, Virginia: Published by Association of Official Analytical Chemist, Inc.. pp. 1141

[7] Anon (1992). Cyperus. The New Encyclopedia Britannica, Macropaedia Chicago,( 3), 185.

[8] Aydin, C. (2002). Physical properties of hazel nuts. Biosystems Engineering, 82 (3), 297-303.

[9] Bamishaiye, E.I. and Bamishaiye, O.M. (2011). Tiger nut: as a plant, its derivatives and benefits. African Journal of Food, Agriculture, Nutrition and Development; 11(5), 5157-5169

[10] Belewu, M.A and Belewu, K.Y. (2007). Comparative Physico-Chemical Evaluation of Tiger-nut, Soybean and Coconut Milk Sources. International Journal of Agriculture and Biology; 9(5), 785-787

[11]Bosch, L. A. and Farre, R. (2005). RP-HPLC determination of tiger nut and orgeat amino acid content. Food Science and Technology International; (11), 33-40.

[12] Braga, G.C.; Couto, S.M.; Hara, T. and Neto, J.T.P.A. (1999). Mechanical behavior of macadamia nut under compression loading. Journal Agricultural Engineering Research; (72), 239-245.
[13]Chevalier, A. (1996). The encyclopaedia of medicinal plants. London, UK: Dorling Kindersley Press. ISBN 9: 980/54, 303148

[14]Chukwu, O. and Sunmonu, M.O. (2010) Determination of selected Engineering Properties of cowpea related to the design of processing machines. Pakistan Journal of Agricultural Engineering.vet.sciences; 26(2), 70-79.

[15] Dutta S.K., Nema V.K. and Bhardwaj R.K. (1998). Physical Properties of grain. Journal of Agricultural Engineering Research;( 39), 259268.

[16]Dyer, A.R. (2006). The ecology of chufa (Cyperus esculentus sativa). University of Carolina, South Carolina,USA http://web.usca.edu/dotAsset/5c46b1f1- 6efe4916-9a63-710bfb736bdc.pdf. Accessed March 2020

[17]Ebrahimzadeh, H., Mirzabe, A.H., Lotfi, M. and Azizinia, S. (2013). Gamma radiation effects on physical properties of squash seeds. Agriculture engineering international: CIGR journal; 15 (1), $131-138$.

[18]FAO/WHO (1985). Energy and Protein Requirements. Report of a Joint FAO/WHO/UNU Expert Consultation. Technical Report Series no. 724. WHO: Geneva. pp. 65

[19]Felix, U.A., and Anthony, O.A. (2011). Determination of some physical Properties of African yam beans. The Pacific Journal of Science and Technology; 12(1), $374-380$.

[20] Fos'hat, M., Etemad, V., Gharibzahedi, S.M.T. and Ghahderijani, M. (2011). Physical, mechanical and aerodynamic properties of Acorn (Quercus suber L.) as potentials for development of processing machines. Australian Journal of Crop Science; (5), 473-478.

[21] Gerald, A.M. and Bonny, E.J. (1976). The biology of Canadian weed Cyperus esculentus L. Canadian Journal of Plant Science; (56), 339350

[22] Gursoy, S. and Guzel, E. (2010). Determination of physical properties of some Agricultural grain. Journal of Applied Science, Engineering and Technology; 12(5), 492 - 498. 


\section{International Journal of Engineering Applied Sciences and Technology, 2020 Vol. 5, Issue 8, ISSN No. 2455-2143, Pages 82-90 \\ Published Online December 2020 in IJEAST (http://www.ijeast.com)}

[23] Heidarbeigi, K., Ahmadi, H., Kheiralipour, K. and Tabatabaeefar, A. (2013). Some physical and mechanical properties of Khinjuk. Pakistan Journal of Nutrition; 8(1), 74-77

[24] Karpoora, N. S. P., Dhananchezhiyan, P. and Parveen, S. (2013). Physical and engineering properties of Tamarinds fruits. International Journal of Scientific Engineering; 2(11), 1083 1087.

[25] Khan, M. I. H., Wellard, R. M., Nagy, S. A., Joardder, M. U. H., and Karim, M. A. (2016b). Investigation of bound and free water in plantbased food material using NMR T2 relaxometry. Innovative Food Science and Emerging Technologies; https://doi.org/10.1016/j.ifset.2016.10.015

[26] Mohapatra, D. and Bal, S. (2012). Physical properties of indica rice in relation to some novel mechanical properties indicating grain characteristics. Food and Bioprocess Technology; (5), 2111-2119

[27] Moshenin, N. N. (1986). Physical properties of plant and animal materials. Gordon and Breach Science publishers New York. ISBN:0677023006

[28] Oladele, A. K. and Aina, J.O. (2007). Chemical composition and functional properties of flour produced from two varieties of tiger nut (Cyperus esculentus). African Journal of Biotechnology; 6(21), 2473-2476

[29] Olaniyan, A.M. and Oje, K. (2002). Some aspect of the mechanical properties of shea nut. Biosystems Engineering; 81 (4), 413-420

[30] Omobuwajo, O. T., Akande, A. E. and Sann, A. L. (1999). Selected physical, mechanical and aerodynamic properties of African Breadfruit (Treculia africana) seeds. J. Food Eng., (40), 41244.

[31] Opadotun, O.O., Adejumo, O.A., Olutu, F.B. and Mohammed, F.A. (2016). Determination of some physical properties of African star seeds. Applied International Journal of Life Science; 5(1), 3134.

[32] Orhevba, B.A., Idah, P.A., Adebayo, S. E., and Nwankwo, C.C (2013). Determination of some engineering properties of dika nut (Irvinga gabonensis) at two moisture content level as relevant to its processing. International Journal Engineering Research and Applications; 3(2), $182-188$.

[33] Panyawong, S., and Devahastin, S. (2007). Determination of deformation of a food product undergoing different drying methods and conditions via evolution of a shape factor. Journal of Food Engineering,https://doi.org/10.1016/j.jfoodeng.2 005.09.012

[34]Pius, E. and Phumuza, M.(2014). Determination of some engineering properties of morana bean. Agricultural Engineering International, CIGR Journal; 16(3), 180 - 188

[35] Razavi, S.M.A. and Edalatian, M.R. (2012). Effect of Moisture Contents and Compression Axes on Physical and Mechanical Properties of Pistachio Kernel. International Journal of Food Properties

DOI: 10.1080/10942912.2010.492541

[36] Shkelqim, K. and Joachim, M. (2010). Determination of physical, mechanical and chemical properties of seeds and kernels of Jatropha Curcas L. Industrial Crops and Products DOI: 10.1016/j.indcrop.2010.04.001

[37] Sirisomboon, P. kitchaya, P., Pholpho, T. and Muhattanyavanitch, W. (2007). Physical and mechanical properties of Jatropha Curcas L. fruits nut and kernels. Biosystem engineering; 97(2), $201-207$

[38] Sitkei, G. (1986). Mechanics of agricultural materials. (Developments in agricultural engineering; 8). Budapest: Elsevier Science and Akadémiai Kiadó

[39] Tunde - Akintunde, T.Y., and Akintunde, B.O. (2004). Some physical properties of Sesame seed. Biosystems engineering; 88(1), $127-129$

[40] Varnamkhasti, M.G., Mobli, V., Jafri,.A., Rafiee, S., Heidarysohanabadi, M. and Kheiralpour, K. (2007). Some engineering properties of paddy (varsazandegi). International Journal of Agriculture and Biology; 9(5), 763-766. 